\title{
雷雨の雨滴荷電と空中電場について
}

\author{
孫 野 長 治・岡部弘

\section{On the Electric Charges of Single Raindrops and Surface Field Intensity under Thunder Clouds}

\author{
By C. Magono \\ Faculty of Science, Hokkaido University, Sapporo \\ and $H$. Okabe \\ Faculty of Liỏeral Arts, Yokohama National University, Yokohama
}

(Manuscript received 31 August 1956)

\begin{abstract}
Electric charges of single raindrops were simultaneously measured for their sizes and surface field intensity under thunder clouds at Kiryu and Yokohama. It was found that a definite inverse relation between the signs of charge and field existed in Japan also, except during the short period when the sign of the surface field changed. The reason of this exception was considered as follows. During the period when the sign of field changed, the field intensity was almost zero. Therefore, the charges of falling raindrops suffered no charge deformation as a result of the capture of ions according to Wilson's theory.

Considering the phenomena, one can explain the wide divergencies observed in the relation between charge and field. To examine Smith's calculation, it is desirable that the charges of many raindrops be observed within a short period in which the field intensity is considered to be constant.
\end{abstract}

\section{§1. 序論}

雨滴の荷電は雷発生機構や空中電気の平衡を調 ベる時の重要な手懸りになるので Elster \& Geitel 以来多くの測定 ${ }^{1)}$ があり，雨滴の個々の荷電が測 れるよらになつてからも, 地上観測では Gschwend $^{4)}$, Chalmers \& Pasquill ${ }^{5)}$, Hutchinson \& Chalmers ${ }^{(6)}$, Smith $^{7)}$, や Gunn ${ }^{8)}$, 航空機による ものでは Gunn \& Devin ${ }^{9)}$ の報告がある。これ らの測定にもとづいて, 雨滴の荷電機構として Simpson の水滴分裂説と Wilson の誘導説が主 として考只らている。乙かし前者は空中電場と 雨滴の荷電の符号が逆のことの多い事実を説明で きないし，後者は符号の関係は説明できても Chalmers ${ }^{10)}$ の指摘しているょうに電場との関係 を説明するのに数十倍のくい違いがある。同一人 の測定值にでも符号も含めて非常なばらつきがあ るので，上の二説だけで完全にかたづくとは考党 られない。従来の報告は平均に重きを物きすぎて いるようであるが，平均で論じるには市まりにも ばらつきが大きいので, 何か別の機構が加わつて いるのではなかららか。ばらつきの原因を調べる

* 北大理学部, ** 横浜国大学芸学部
には時間的变化に注目するのも一つの方法であろ ら。また水滴分裂, 誘導のぞちらの機構にしても 空中電場の同時測定が重要であるから，われわれ は両者の時間的変化に着目して 1954 年の夏から 秋にかけて桐生々横浜で雷雨からの 159 ケの雨滴 の荷電を観測した。

雨滴の荷電の観測は珍しいことではないが，こ の種の観測は地球上で広範囲に行われることが望 ましいことと，時間的変化で若干の知見が壳られ たのでとりあえず報告する。

\section{§2. 測 定装置}

i) 空中電場

林に囲まれた広い開地に空中線として地上 $1 \mathrm{~m}$ そ $5 \mathrm{~m}$ の高さに裸銅線を Fig. 1 のように張り, これを Hankel 型の電位計に導いて地表との電位 差をはかつた。空中電場の強さによつて空中線と 電位計の補助電圧をきりかえた。集電器はつかわ なかつたが，雷雨が近づけば銅の空中線だけで充 分電場の変動が表れた。空中線をきりかえる時に 火花がとんだ位である。電位計の目盛の検定は空 中線附近をるらそくの炎でイオン化して行つた。 


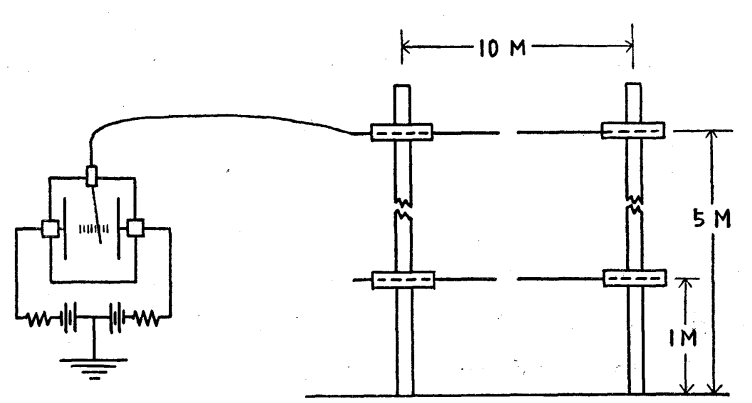

Fig. 1. Apparatus for measuring surface field intensity.

この時の係数は 20 倍である。この係数は大きい ので精度はめまり良くないが，大体の傾向を知る にはこれで充分である。空中線の支持部の絶縁も 雪片 ${ }^{14)}$ の場合と同様に大型のろ た。絶緑は充分であるが日射のために軟化したこ ともあるのでなるべく白色のものがよい。日射の 雨よけのために覆をつけたはらがよかつたか子知 れない。

平面更正は施さなかつたが大体平地と考えてよ い所で女る。以上を考慮して空中電場の測定誤差 は 10 割程度と考光られるので量的に精密な議論 は避ける。 ii） 雨滴の荷電の測定

荷電の測定装置は雪片 ${ }^{14)}$ の場合々同様に真 空管 1R5 の第 3 格子につないだ受板に雨滴 を 1 ケだけ受け，このために生じた陽極電流 の変化を直流增巾して読みをとつた。雷雨の ためか荷電量は $10^{-2} \mathrm{esu}$ 程度に大きかつたの で測定が容易であり指針の戻りも速いので 30 秒に 1 ケの割合ではかることができた。電気 量と陽極電流計のふれとの検定も雪片の場合 と同様，既知の電圧と大きさを持つ水滴を孤 立したところから終端速度で括として行なつ た。水滴は雨滴と全く同じ状態で落らるので 精度もよく問題も少い。雨滴荷電の測定誤差は 1 割内外々考学られるので空中電場に比べれば充分 な精度である。

iii) 雨滴の質量

受板上に東洋沪紙 No. 1 (径 $7 \mathrm{~cm}$ ) を特いて痕 跡から雨滴の大きさを求めた。汇紙は雨滴の分裂 を防ぐ効果もあり，検定の結果によればレナード 効果も無視できる程度であつた。

\section{$\S 3$. 測 定 結果}

雨滴の荷電，大きさ及び電場の関係については 種々の見かたがあるので生の観測結果を Tables I-IV に示す。

Table I. Obs. No. 1. Thunderstorm at Kiryu 11.56-12.32 1 Aug. 1954.

\begin{tabular}{r|c|c|c||r|r|r|c}
\hline Time & Field $v / \mathrm{cm}$ & Charge 10-.2 esu & Diameter mm & Time & Field $v / \mathrm{cm}$ & Charge 10-2 esu & Diameter mm \\
\hline 1156 & +28 & +0.3 & 0.8 & 1223 & -30 & +5.4 & 2.2 \\
1202 & +28 & -1.0 & 1.0 & 25 & -68 & +26 & 3.5 \\
10 & +14 & -1.0 & 1.3 & 30 & -32 & -1.0 & 1.2 \\
17 & -56 & +3.5 & 1.3 & 32 & +10 & -1.0 & 1.4 \\
20 & -30 & +5.3 & 2.0 & & & & \\
\hline
\end{tabular}

Table II. Obs. No. 2. Thunderstorm at Kiryu 16.03-16.52 5 Aug. 1954.

\begin{tabular}{c|c|c|c||r|r|r|c}
\hline Time & Field $v / \mathrm{cm}$ & Charge 10-2 esu & Diameter mm & Time & Field $v / \mathrm{cm}$ & Charge 10-2 esu & Diameter mm \\
\hline 1603 & -20 & -0.1 & 1.4 & 1627 & -68 & +1.1 & 1.5 \\
035 & -32 & -1.3 & 1.2 & 28 & -94 & +2.8 & 1.7 \\
04 & -64 & -4.6 & 1.9 & 30 & -96 & +6.3 & 2.0 \\
05 & -40 & -0.6 & 1.3 & 32 & -96 & +0.5 & 1.8 \\
07 & +34 & -1.3 & 1.7 & 38 & -80 & +0.8 & 2.0 \\
08 & +43 & -0.3 & 1.7 & 39 & -80 & +0.7 & 1.7 \\
10 & +67 & -2.7 & 1.6 & 41 & -74 & +0.5 & 1.4 \\
13 & +24 & -1.3 & 1.6 & 42 & -50 & +0.3 & 1.7 \\
15 & +38 & -0.1 & 1.5 & 43 & -50 & -0.1 & 1.1 \\
16 & +56 & -0.9 & 1.4 & 44 & -20 & +0.4 & 1.6 \\
17 & +14 & +1.4 & 2.2 & 45 & -20 & +1.0 & 1.0 \\
18 & -48 & -1.8 & 1.5 & 46 & -20 & +1.0 & 1.1 \\
\hline
\end{tabular}


Table II.

(Continued)

\begin{tabular}{r|c|c|c||c|c|c|c}
\hline Time & Field $v / \mathrm{cm}$ & Charge 10-2 esu & Diameter mm & Time & Field $v / \mathrm{cm}$ & Charge 10-2 esu & Diameter mm \\
\hline 1619 & -60 & -2.6 & 1.4 & 1647 & -21 & -0.4 & 1.5 \\
20 & -68 & -0.9 & 1.3 & 48 & -21 & +0.4 & 1.7 \\
22 & -66 & -3.5 & 1.7 & 49 & -21 & 0 & 1.0 \\
23 & +24 & +0.9 & 1.4 & 50 & -10 & 0 & 1.5 \\
24 & -68 & +1.6 & 1.8 & 51 & 0 & 0 & 1.0 \\
26 & -96 & -2.4 & 2.1 & 52 & +8 & 0 & 1.0 \\
\hline
\end{tabular}

Table III. Obs. No. 3. Thunderstorm at Yokohama 12.19-19.01 17 Sept. 1954.

\begin{tabular}{|c|c|c|c|c|c|c|c|}
\hline Time & Field $v / \mathrm{cm}$ & Charge $10^{-2} \mathrm{esu}$ & Diameter $\mathrm{mm}$ & Time & Field $v / \mathrm{cm}$ & Charge $10^{-2} \mathrm{esu}$ & Diameter $\mathrm{mm}$ \\
\hline 1219 & +0 & -0.8 & 2.1 & 1320 & -0 & +1.4 & 2.0 \\
\hline 21 & +0 & -0.3 & 1.4 & 22 & -46 & -0.1 & 1.6 \\
\hline 22 & +0 & +0.6 & 2.2 & 24 & -30 & +0.8 & 1.9 \\
\hline 25 & +0 & +0.3 & 2.2 & 25 & -5 & 0 & 2.0 \\
\hline 28 & +29 & +0.6 & 3.1 & 27 & -0 & -0.9 & 1.4 \\
\hline 30 & -34 & +0.6 & 2.3 & 29 & -0 & -0.3 & 2.4 \\
\hline 31 & +11 & +1.3 & 1.6 & 31 & -0 & +0.9 & 2.2 \\
\hline 32 & +29 & +0.7 & 1.4 & 33 & -0 & +0.2 & 1.6 \\
\hline 34 & +10 & +7.9 & 3.4 & 35 & -0 & +0.2 & 1.6 \\
\hline 35 & -42 & +1.8 & 1.3 & 36 & -0 & -0.6 & 1.6 \\
\hline 36 & -56 & -0.2 & 2.1 & 37 & -0 & -1.4 & 1.9 \\
\hline 37 & -35 & -0.2 & 1.3 & 39 & +0 & -1.5 & 1.9 \\
\hline 39 & -56 & -0.6 & 1.5 & 40 & +0 & -0.6 & 1.6 \\
\hline 40 & -0 & +0.1 & 1.5 & 42 & +11 & +0.7 & 1.6 \\
\hline 42 & -56 & -0.1 & 1.9 & 44 & -54 & -0.9 & 1.6 \\
\hline 45 & -56 & -1.6 & 1.7 & 46 & -59 & +0.2 & 1.9 \\
\hline 46 & -44 & -0.1 & 1.9 & 47 & -0 & +0.1 & 1.6 \\
\hline 47 & -50 & -0.6 & 2.1 & 1406 & -0 & -0.6 & 1.5 \\
\hline 48 & -34 & -2.9 & 3.1 & 08 & +13 & -0.2 & 0.9 \\
\hline 49 & +10 & +0.3 & 1.6 & 27 & -0 & +2.8 & 2.8 \\
\hline 50 & +12 & -0.1 & 1.4 & 28 & -0 & +3.0 & 3.0 \\
\hline 51 & +12 & +1.2 & 1.5 & 29 & -0 & -1.6 & 2.6 \\
\hline 52 & +11 & +0.3 & 1.5 & 30 & -0 & +2.2 & 2.4 \\
\hline 53 & -4 & +1.2 & 1.0 & 32 & -0 & +1.4 & 2.4 \\
\hline 54 & -35 & +0.1 & 1.0 & 33 & -0 & +1.8 & 2.4 \\
\hline 56 & -34 & +0.1 & 1.0 & 34 & -0 & +3.5 & 2.8 \\
\hline 57 & -50 & +0.1 & 0.9 & 35 & -0 & +3.1 & 2.4 \\
\hline 58 & -64 & -0.1 & 1.2 & 36 & -0 & +1.4 & 1.5 \\
\hline 59 & -54 & 0 & 0.7 & 38 & -70 & +0.6 & 1.1 \\
\hline 1301 & -35 & 0 & 1.1 & 40 & +14 & +0.3 & 1.9 \\
\hline 02 & -53 & -1.8 & 2.2 & 41 & -0 & +0.3 & 2.1 \\
\hline 03 & -58 & -0.3 & 1.9 & 45 & -0 & 0 & 2.0 \\
\hline 05 & -36 & 0 & 1.6 & 46 & -47 & +0.1 & 1.6 \\
\hline 07 & -74 & 0 & 1.4 & 48 & -55 & +2.1 & 3.0 \\
\hline 11 & -0 & +0.6 & 1.5 & 57 & -34 & +1.4 & 1.7 \\
\hline 13 & -0 & +0.7 & 1.4 & 1858 & -37 & +1.1 & 2.8 \\
\hline 15 & +34 & -1.4 & 1.5 & 59 & -47 & +0.5 & 1.9 \\
\hline 16 & +0 & -8.0 & 2.0 & 1900 & -41 & +0.3 & 1.9 \\
\hline 18 & +0 & -5.5 & 2.1 & 01 & -39 & +0.1 & 2.0 \\
\hline 19 & +0 & +1.4 & 1.6 & & & & $\ldots \ldots$ \\
\hline
\end{tabular}


Table IV. Obs. No. 4. Typhoon 14 at Yokohama 20.05-22.26 18 Sept. 1954.

\begin{tabular}{r|c|c|r||r|r|r|r}
\hline Time & Field $v / \mathrm{cm}$ & Charge $10^{-3}$ esu & Diameter mm & Time & Field $v / \mathrm{cm}$ & Charge $10^{-3}$ esu & Diameter mm \\
\hline 2005 & -40 & +0.4 & 1.5 & 2040 & 0 & 0 & 1.4 \\
06 & -32 & +2.5 & 2.3 & 2111 & -42 & 0 & 2.0 \\
10 & -59 & +4.0 & 1.8 & 16 & -10 & 0 & 1.4 \\
11 & -54 & +4.0 & 2.2 & 18 & 0 & 0 & 1.2 \\
13 & -70 & +5.5 & 1.4 & 20 & 0 & 0 & 1.5 \\
15 & -39 & +2.5 & 2.1 & 24 & -10 & 0 & 1.5 \\
16 & -30 & +2.5 & 2.4 & 26 & 0 & +0.4 & 2.0 \\
18 & -74 & 0 & 1.7 & 30 & -59 & +1.0 & 2.0 \\
20 & -39 & +0.4 & 1.5 & 33 & -40 & +2.5 & 2.4 \\
23 & -65 & +2.5 & 2.1 & 35 & -40 & +0.4 & 1.2 \\
25 & $-\mathrm{S} .0$. & +4.0 & 2.1 & 40 & +40 & 0 & 1.7 \\
27 & -28 & 0 & 1.7 & 41 & +40 & 0 & 1.3 \\
29 & -32 & +2.5 & 2.1 & 2214 & -13 & 0 & 1.4 \\
30 & -40 & +0.4 & 2.5 & 15 & -53 & +2.5 & 2.3 \\
31 & -52 & 0 & 1.9 & 24 & -40 & 0 & 2.3 \\
34 & -30 & 0 & 2.2 & 25 & -24 & 0 & 1.5 \\
36 & -44 & 0 & 1.7 & 26 & -11 & 0 & 1.7 \\
38 & -10 & +1.0 & 1.4 & & & & \\
\hline
\end{tabular}

Fig. 2 は 1954 年 8 月 1 日, 桐生市に抒 ける雷雨の一例 (Table I, Obs. No. 1) であ る。横軸は時刻で黒丸印が雨滴の荷電（数字 は直径 $\mathrm{mm}$ ) を示し, 実線はその時の空中電 場である。最初, 雨滴が弱い負の荷電をもつ ていたが，その時の電場は正 (上空が正)であ り, 電場が負にかわると正荷電の雨滴が観測 された。一方, 電場が強いほど, また雨滴が 大きいほど荷電の大きいことがわかる。

Fig. 3 は同じく 8 月 5 日 (Table II, Obs. No. 2) の雷雨でめる。始の正電場 (16 時 5

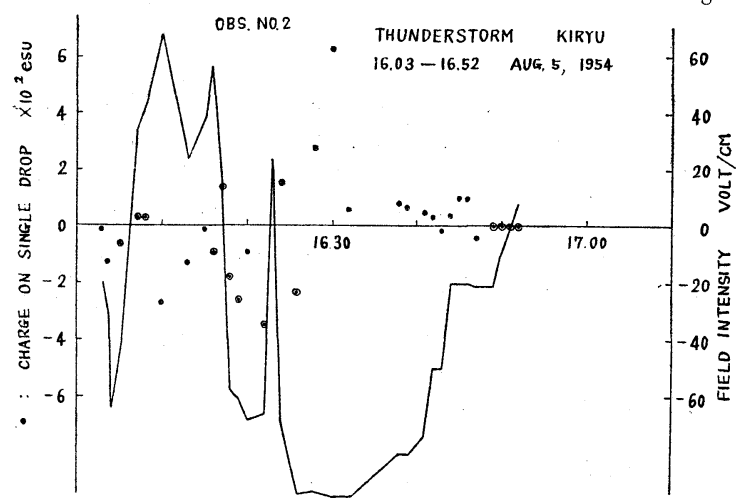

Figs. 2 and 3. Charges on single drops (black dots) and surface field intensity (solid line) as a function of time.

Marks $\odot$ represent charges observed for the period of $2 \mathrm{~min}$. when the sign of a filed reversed.

Numbers attached to black dots show diameters of raindrops in $\mathrm{mm}$.
分-15 分) の時には負の雨滴, 後の負電場の 山 (16 時 20 分-50 分) では正の雨滴が観測 された。後者の負電場の山は雷雲の中の一つ の Cell の消長を表わすものであろうか。Obs. No. 1 と異なるのは, 電場の符号が転換する 前後に観測された雨滴の荷電の符号は電場符 号と一致するのが多くみられたことである。 電場符号転換時の前後 2 分以内に観測した 荷電は特に○印で示してある。9月にはいつ てから横浜市で観測をおこなつた。

Fig. 4 は横浜の前線性の雷雨 (Table III, Obs. No. 3) の例であるが電場符号の交錯の 烈しい点を除けば桐生の夏の雷雨と同じよう な傾向である。以上の 3 例を通じて雷雲から の雨滴の荷電は $10^{-2}$ eus 単位で, 従来の観測 值と変つていない。

Obs. No. 3 の翌日, 台風 14 号 (1954) が 

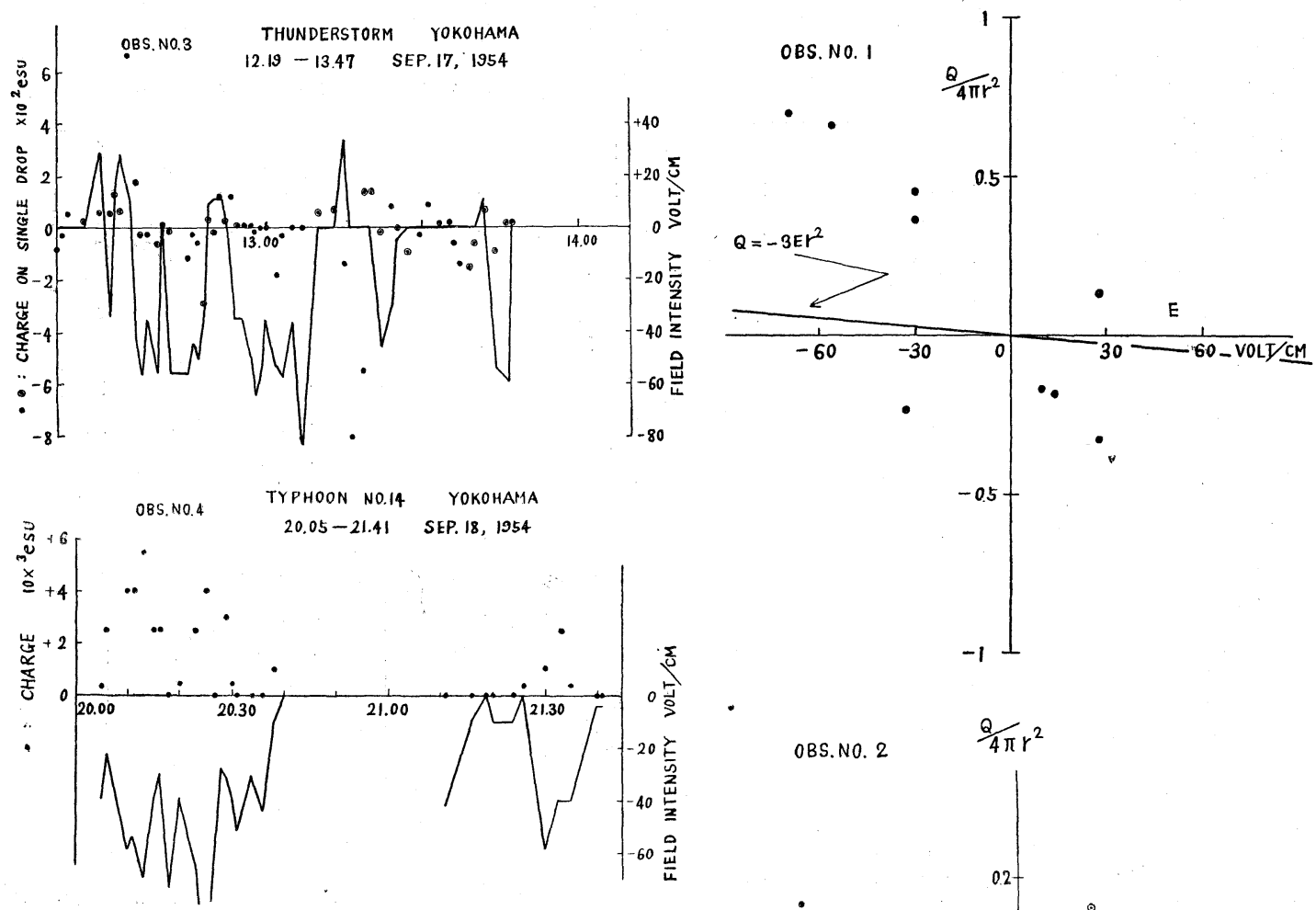

Figs. 4 and 5. Charges on single drops (black dots) and surface field intensity (solid line) as a function of time.

来襲した。Fig. 5 (Table IV, Obs. No. 4) がそ の時の結果で雷雨ではなく, 荷電も前の例に比べ て1桁小さい。また電場は常に負で, 荷電は汪之 んぞ正であつた。これが通常の降雨の型と思われ る。以上の 4 例索通じて空中電場変動の周期は大 づかみにいつて 40 分〜 60 分であり, 所謂 Wave Pattern $^{2)}$ よりも少し短いが同様なものであろう。

\section{§4. 考察}

i) 雨滴の荷電と空中電場の符号

Figs. 2〜5 に示されているように，空中電場の 符号の転換時を除けば，荷電と電場の符号は泀々 えど逆である。この事実は欧州の多くの観測者 ${ }^{11}$ によつて注意されたことで嵓り，吾国でも戦前の 前橋の雷雨観測の畠山阳) の報告にも述べられてい るが，この符号の逆関係は Wilson の誘導説に非 常に有利にみえる。

そこで符号だけでなく電場との関係を量的に調 ベてみよう。この場合, 雨滴の大きさによる影響 を除く必要があるから，雨滴の単位表面積岕たり の荷電と電場の強さの関係を調べてみる。

Figs. 6〜9 は前述の 4 例をいまの方法で整理 したもので, 縱軸が単位表面積女たりの荷電（○ 印は電場符号転換時), 横軸が地表で測つた空中電

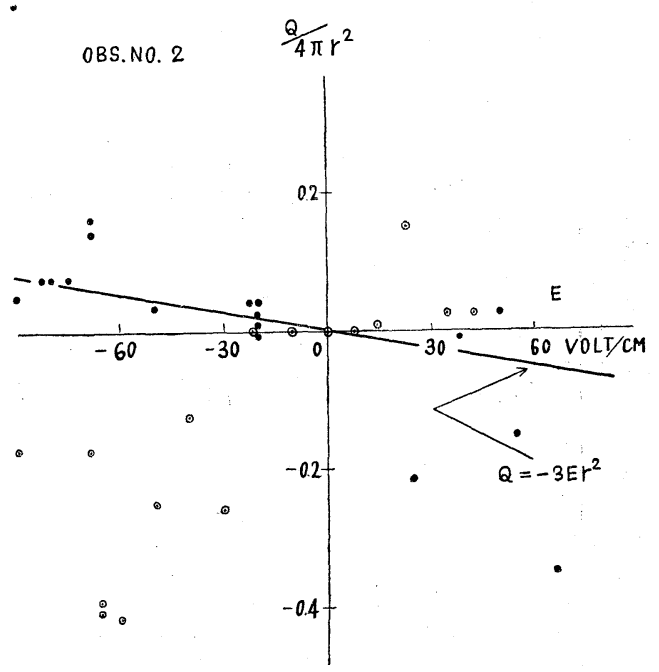

Figs. 6 and 7. Relation between $Q / 4 \pi r^{2}$ and surface field intensity $E$.

場の強さで岁る。Fig. 6 では 2 ケの例外はめる が，測点は原点を通つて第 2 , 第 4 象限にのびる 直線上にのつている。これは，大きさの影響を除 けば，荷電と電場の強さの間には符号は逆でめる が大きさは比例する関係のあることを示するので ある。この時は測定值が少な過ぎるが, Figs. 7, 8 でもの印を除けば同様な傾向がみられる。Fig. 9 では測点は第 2 象元だけに集中しているが同傾向 である。次に Wilson の誘導機構を基にして計算 した下記の Whipple 等 ${ }^{13)}$ の式と量的に比べてみ よう。

$$
Q=-3 E r^{2}
$$

$Q$ は電場の強さ $E$ の空気中に同符号のイオン 
だけが存在する時に，この中を落下する半径 $\boldsymbol{r}$ の 雨滴のもつ最大電気量である。正負イオンが等量 存在するときは

$$
Q=-0.5 E r^{2}
$$

になる。(1)式を図示したのが Figs. 6〜9 の実線 である。これと比べてみると，荷電の観測值は

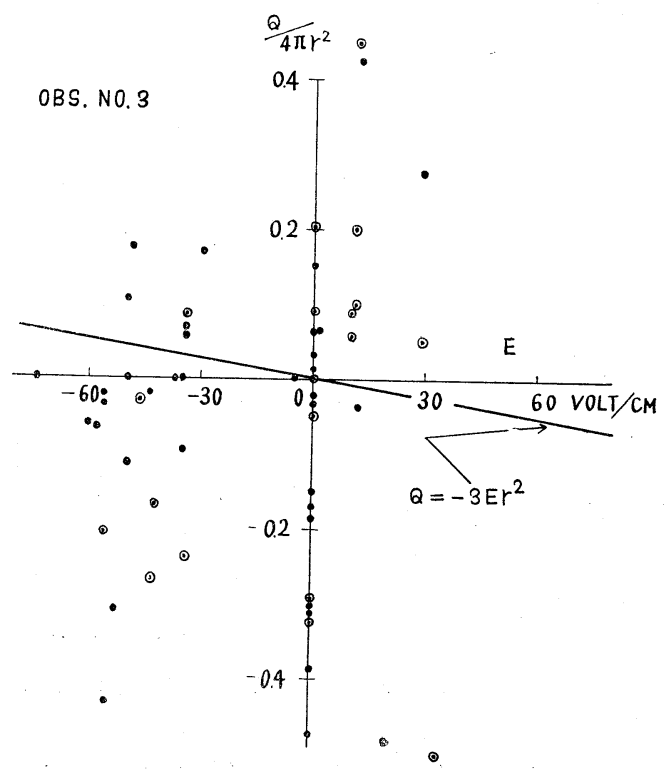

OBS. NO. 4

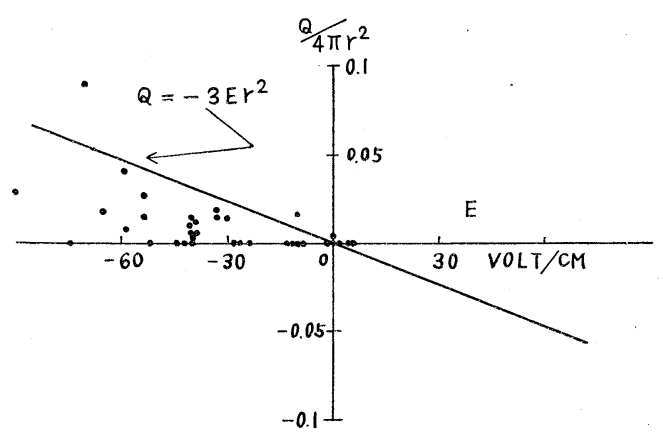

Figs. 8 and 9. Relation between $Q / 4 \pi r^{2}$ and surface field intensity $E$.

Fig. 9 の場合を除けば計算值より数倍大きい。こ れを空中電場や荷電の観測誤差のみによるものと は考えられない。

計算值よりも観測值が遥に大きいということは 雲底直下の空中電場が地上で測つた電場より強い ことに相当する。この通りならば Chalmers ${ }^{10)} の$ 提出した疑問への好い答になるわ梳である゙，測 定精度をもつと高めてからでなくては断定できな い。 ii）観測值のばらつき

Figs. 6〜9 でみられるよ5に，一般には測点が 第 2 , 第 4 象元にあり, 電場転換時には区対に第 1, 第 3 象元に集まる傾向が顕著である。これは 理由のあることに相違ない。この理由について考 えてみよう。

a) 荷電と電場の観測時刻のずれ

荷電のよみをとつて記録した直後に電場を測つ た。この間のずれは最大 1 分, 平均 20 秒くらい であつた。

いま簡単のために電場が Fig. 10 の実線で示す よ5に周期 60 分の $\sin$ 曲線で変動し, これに応

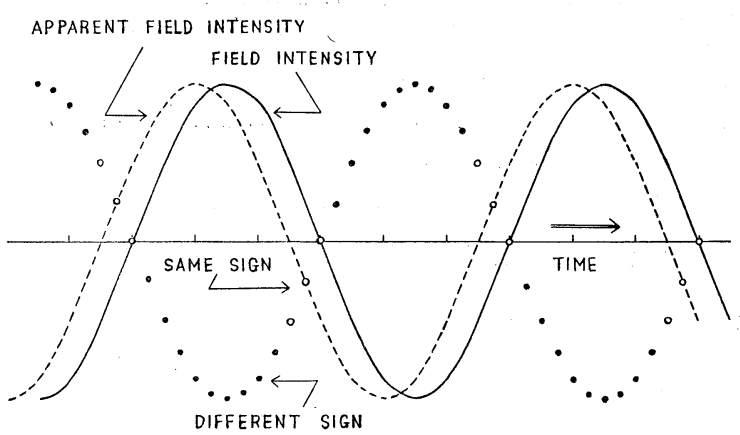

Fig. 10. Charge and field intensity as a function of time. Black dots show the sign of charge same as that of field, white dots, different sign.

じて雨滴（大きさ一様と仮定）の荷電は (1) 式の関 係で変つてゆくものとする。かりに電場のよみが 誇張して 5 分間和くれたものとすれば電場は Fig. 10 の波線の如く記録される筈である。この場合, 図の白丸印で示す如く，記録された見かけの電場 が正に変つた直後 5 分間内に観測された雨滴は正 荷電でその時の電場の符第々一致する。同様に電 場が負に变つた直後にも同符号の負の荷電がみら れる筈である。乙かし Figs. 3, 4 にみられるょう に実測の場合は同符号荷電は電場転換時の前後に ばらついている。また Fig. 10 からわかるよら に, 5 分の括くれでも, 同符号と観測される荷電 の大きさは逆符号の場よりも遥に小さい。実際の 特くれは 1 分以内であるから，雨滴の大きさに変 動があつたにしろごく小さい筈である。ところが Figs. 3，4 の同符号の荷電は逆符号のものと同程 度である。大きさを考慮した Figs. 7,8でみると 同符号の方が反つて大きいくらいである。.したが つて観測時刻の都くれのためとは考光られない。

b) 電場と荷電現象間に和くれが実際に存在す る場合

この場合も a) 同様に電場符号の転換時に同符 号の雨滴が観測されることになる。Figs. $2 \sim 4$ で みると電場と荷電は半周期 20 分程度の変動でる 
忠実に逆符号関係で追随して挍り，位相に特くれ があつたにしても観測值からは一応は数分と考光 られる。絶縁のよい空気中で粒子の荷電は 1 時間

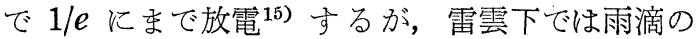
荷電は補給がなければ数分で放電してしまうであ ろう。また雨滴が雲底でイオンを吸着しはじめる 高さは Chalmers ${ }^{12)}$ の計算によれば 800〜 $1000 \mathrm{~m}$ であるから，地上に達するまでの時間は， 2,3 分 である。このように荷電の执くれが 2,3 分とす れば a)で述べたと同じ理由で，同符号と逆符昘 の荷電が同じくらいであるという実測の説明が難 乙くなる。もし位相の拉くれが $\pi / 4$ (時間で 15 分）ならば同符号の大荷電の雨滴が観測されるこ とになるが，それならば Figs. 2〜4 で，その特 くれが見られそうなるのである。しかし鬼に角, 2,3 分の拉くれを問題にするには雨滴荷電の観測 速度をるら少し增さなければなるまい。

c) 電場の転換時に観測された同符号に対応す る気象現象が上空で実際に拈きる場合。

たとえば雷雲下部の負電荷の雨滴や $\boldsymbol{p}$-charge - $^{16)}$ 部から Simpson 水滴分裂により正に荷電した雨 滴が丁度電場符号の転換時に落下すれば, 電場の 影響を受けないでそのまま地上に到達すると考兄 れば一部の実測が説明される。

d) 雨滴の荷電には影響しないが，地上の電場 を支配するような現象による場合。

雨滴の飛沫による空間電荷が地上附近にたまる ことも考兄られるが7), 雷雲による電場に打勝つ ほぞ強いるのであうらか。これを確めるには地表 からもつと離れたところで電場を測る必要があ る。

a)，b)，c）及びd) の何れにして子電場, 荷電, 測時の測定精度を高め, 観測例ももつと集積して から改めて検討したい。ただ Gunn ${ }^{8)}$ の結果の如 く荷電が電場の符号に無関係にばらつくような場 合でる，電場符号の転換時に注意すれば更に事情 がはつきりするのではないかと考えられる。

電場の変化々荷電の変化は，どちらが原因であ るかはわからないが, 電場符号の転换時を除け ば，逆符号関係で非常によく追随しあつている。 したがつて雨滴の荷電の正負いづれが多いかを論 じるには電場の正負も合せ考える必要があろう。 $\mathrm{Smith}^{7)}$ は雲底から雨滴が落下し始める時の荷電 (表面積に比例).が途中で Wilson の誘導機構で反 対符号のイオンを吸収するために変化する状態 を，雨滴の大きさの函数として計算した。定性的 に要約すれば, 大雨滴は速く落下するから元の符 号の電気を残して地表に到達するが，小雨滴は掠 そいから途中で符号が変つてしまう。微小雨滴の 荷電はいずれにしろ零に近い。彼の計算した雨滴 の荷電と大きさの関係は Fig. 11 の実線のような 形をとる。これに他の原因が加わつてばらつけば
Fig. 11 の破線のように正負に拡がる。彼の計算 と比較のために Obs. No. 2 を大ささと荷電の関 係で図示したのが Fig. 11 である。図でみると雨

OBS. N0. 2

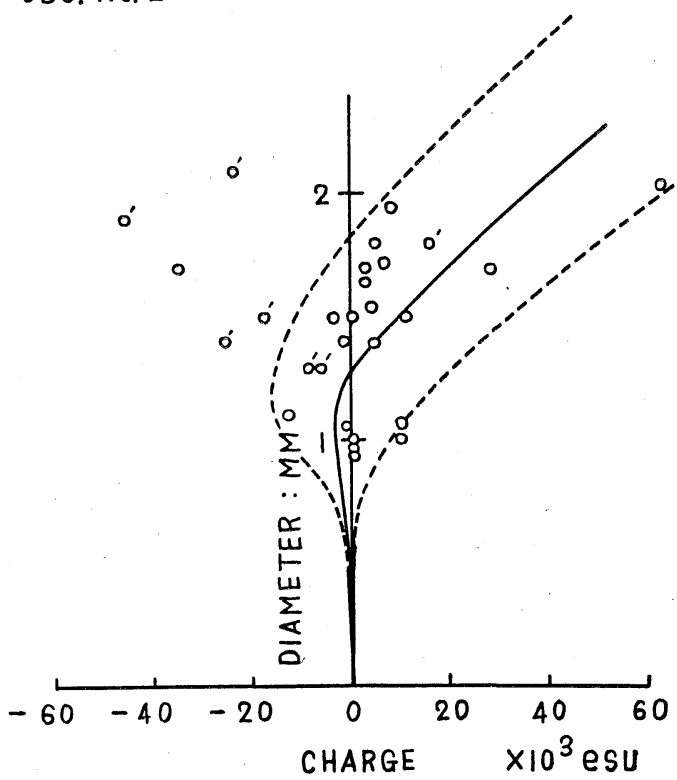

Fig. 11. Relation between diameters and charges observed when surface field was negative. Dashed dots show the values observed when the sign of a field reversed.

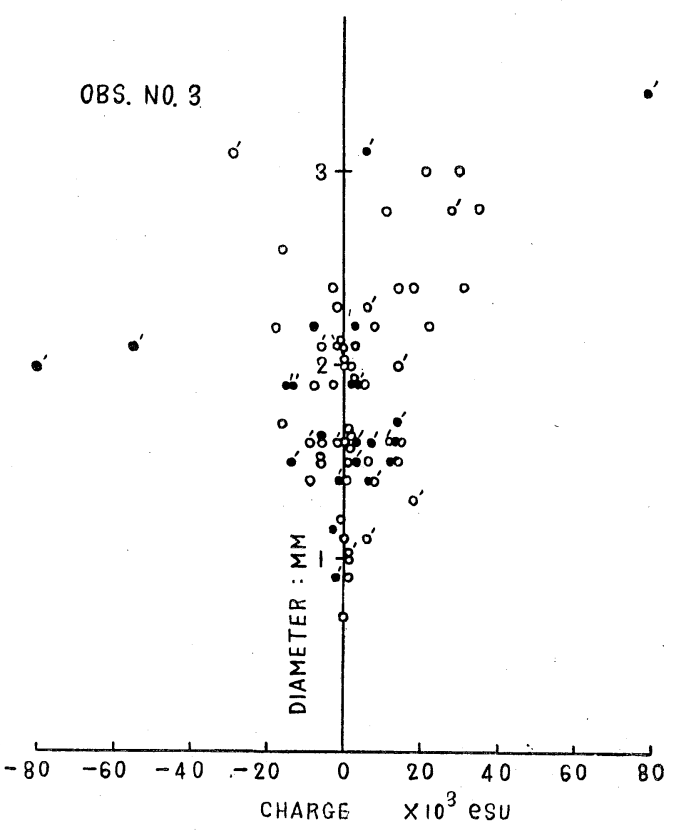

Fig. 12. Relation between diameters and charges. White dots represent the values when the field was negative, and black dots, when positive. 
滴が大きい汪ど荷電も大きいが符号は正負等分に ばらついている。ただ電場の転換時のものをダッ シで区別すれば図の破線の範囲に収まり，如何に も雲底を出発する時に正電荷だつた雨滴が途中に 変化したようにみえる。しかし Obs. No. 2 では電 場が正, 負に変つていたからみかけだけでは論ぜ られない。Fig. 12 は Obs. No. 3 の電場が正の 時の荷電を黒丸印, 負の時を白丸印, 転換時には ダッシを附して区別して表示したものであるが， 転換時に極端に大きい荷電の雨滴がみられたと いう他には特別の傾向はないようである。 Smith のあげた例では 3〜4 時間ごとに区切つて観測結 果を整理しているが，その間に電場の符号に変化 はなかつたであるうか。彼の計算を観測で検討す るには電場に变化のないことが必要で,できれば 一時に多数の雨滴の荷電を測ることが望まれる。

この観測は筆者等が横浜国大在任, 在学中に行 われたものである。桐生市での観測にあたつては 群馬大工学部の忍足舜吾氏に多大の沶世話にあら゙ かつた。記して深く謝意を表わす。本研究は文部 省科学研究費で行われたものである。

\section{References}

1. 畐山久令, 川野実 (1955): 気象電気学, 岩波, 166 .

2. " " " 78 .

3. " " "

4. Gschwend, P. (1920): Beobachtung über die elektrischen Ladungen einzelnen Regentropfen und Schneeflocken. Jb. Radio akt., 17, 62-79.

5. Chalmers; J. A. and F. Pasquill (1938): The Electric Charge on Single Raindrops and Snowflakes. Proc. Phys. Soc. London, 50,
1-16.

6. Hutchinson, W. C. A. and J. A. Chalmers (1951): The Electric Charges and Masses of Single Raindrops. Quart. Jour. Roy. Met. Soc., 77, 85-95.

7. Smith, L. G. (1955): The Electric Charge on Raindrops. Quart. Jour. Roy. Met. Soc., 81, 23-47.

8. Gunn, R. (1947): The Electrical Charge on Precipitation at Various Altitudes and Its Relation to Thunderstorms. Phys. Rev., 71, 181-186.

9. Gunn, R. and C. Devin (1953): Raindrop Charge and Electric Field in Active Thunderstorms. Jour. Met. 10, 279-281.

10. Chalmers, J. A. (1949): Atmospheric Electricity. Oxford, 99.

11. Chalmers, J.A. (1949): Atmospheric Electricity. Oxford, 113.

12. Chalmers, J. A. (1951): The Origin of Electric Charge on Rain. Quart. Jour. Roy. Met. Soc., 77, 249-259.

13. Whipple, F. J. W. and J. A. Chalmers (1944): On Wilson's Theory of the Collection of Charge by Falling Drops. Quart. Jour. Roy. Met. Soc., 70, 103-118.

14. 孫野長治, 他 (1956): 雪片の荷電について. 気象 集誌, Ser. II, 34, 41-49.

15. Wössner, R. H. and R. Gunn (1956): Measurements Related to the Fundamental Processes of Aerosols Electrification. Jour. Colloid Sci., 11, 69-76.

16. Schonland, B. F. J. (1953): Atmospheric Electricity, Methuen, 60. 